\title{
CHARLES UNIVERSITY IN PRAGUE: BETWEEN THE GERMAN AND CZECH ACADEMIC TRADITION
}

\section{Summary}

Charles University is oldest in Central Europe and it was founded by initiative of Charles IV from Luxembourg dynasty, himself a ruler famous by his role in patronizing and developming culture and science.

While Charles University was an integral part of Prague and Bohemian cultural life, it was involved in political controversies of the epoch, such as the Czech reformation in XVth c., and 30 Years War in XVIIth c.Nowadays we do not realize that the university was dominated by German language and tradition but significant change happened after 1918 when Czech state was reborn. This provoked even the split between German and Czech academia, follwed by foundation of German speaking university outside of Prague. This paper will be focused on these dramatic years of finding the new concept of a national Czech university, its shortlived high ranking popularity at European level between the wars and the dark period of German occupation.

Key words: Charles University, Charles IV Luxembourg; German and Czech academic traditions

Founded around 1347 and 1349 , Charles University is oldest in Central Europe and was remarkable initiative of Charles IV from Luxembourg dynasty, himself a ruler famous by his role in patronizing and developing culture and science. Acknowledging this it proudly bears his name and currently is one of the leading academic centres for developing humanities and social sciences. The differences in dating are following the institutional actions in laying down its foundations as firstly it received Pope

1 petrus@uni-plovdiv.bg 
Clement VI bulla establishing a university which would copy the model of Sorbonne.

In 1348 Charles IV as King of Bohemia issued a Golden Bulla with royal privileges, which was reiterated in 1349 , when he was crowned as a Roman Emperor. But due to anticlerical tendencies in XIX c., the earliest date was neglected as being provided by the Catholic Church, whilst rising patriotism of these years gave priority to the king as real founder of the university.

While Charles University since it beginnings was an integral part of Prague and Bohemian cultural life, it was also heavily involved in political controversies of the epoch, such as the Czech Reformation in XVth century, and Thirty Years War in XVII-th century.

We often look on the past with the eyes of today's advantage of knowing well the past events. But it is not always so, even our current perceptions might be wrong or manipulated, but in most of the cases we simply ignore very important details of the past. Such is the case with looking the glorious history of Charles University

As Medieval university, it was normally founded under the scholarly tradition of its time and thus the Latin was the only language of instruction and official communication. Besides, the very existence of this academic centre reflected the characteristics of the urban life in Prague at that time.

As important metropolis of the Luxembourg dynasty the city combined long developing traditions from previous centuries. The city had multifacetic features, joining together a number of ethnicities but in this diversity the German element was leading as also were inhabitants with German origin in Prague.

Though there is not a direct link between the university as institution and its creator, it is very clear that the very foundation of this scholarly center, first of its kind in the heart of Europe, it resembled much of the personality of the patron. First of all, Charles IV spent seven years of his childhood in Rome and then in Paris and was able to receive high profiled academic education at very early age. He was offered to assist lectures at Sorbonne and one of his mentors was the cardinal Pierre Roger de Rosieres, future Pope Clement VI.

Born in Prague and half Czech by his mother side, Charles IV had deep devotion to his Slavic roots and it is remarkable that after returning from abroad his knowledge of Czech language was quite limited, so he 
on his own invested much energy to learn it again. Very much conscious about the importance of the Slav culture he managed to provide right to have liturgy in Czech language at the local religious site Na Slovanech - or Emauzsky klaster (Emmaus Monastery), an extraordinary exception in the Latin dominated Catholic world during that epoch.

Thus we may resume that Charles IV had a clear vision about creating from Prague a new Medieval Rome which comprised wise combination of promoting local language in religious services and creating high profile academic institution as university, which would compete successfully all other European scholarly traditions. Charles IV consistently supported extensive use of the local Czech language giving equal importance to German as leading cultural trend in Central Europe. To this wise diplomatic staunch he added support to other cultural institutions, such as production of books and special manuscript paintings school. He was also very much aware of the importance of local businesses end developed further Prague by expanding the city through creation of new urban settlement as Nove Mesto bringing together a new amount of local citizens which would better combine the predominant German fashion habits with local Czech roots.

Because of all these systematic efforts and wise diplomatic rule Prague indeed was converted into a new leading cultural center for Europe, in much to envy of other European lands. It is well known Petrarca's personal letter to the king asking him for same equality in bringing support to the culture in the Italy, which by fashion during these decades was replaced by Prague and Bohemia (Cit. Bohumil Vurm and Zuzana Foffova"Praga Mystica and Karelek IV as Pater Patrie, Praha, 2016).

From the very beginning Church was closely involved into regular teaching not only in the Theological Faculty, but giving the shape to all studies as part of the classical "Trivium". With such wise support from the king and reflecting the richness of urban cultural settlement of late Medieval Prague, the university shortly was involved in local political clashes. When early Protestant turmoils appeared in Europe, they rapidly found reflection in Prague, thus commencing the era of Reformation. In 1403 Jan Hus as Dean of the Faculty of Philosophy translated into Czech the "Trialogue" of John Wycliff and notwithstanding the ban of these heresies from the rectory, the new doctrine flourished in popularity. 
During the first Protestant schism in 1408 Jan Hus as newly elected rector supported pro-Bohemian sentiments of the King Vaclav (Wenceslaus) who issued Kuttenberg decree in January 1409 and abolished university constitution. This direct royal involvement was considered as nationalist coup as it gave priority to Bohemian component in the university where previously Czech students were only up to $20 \%$. As result in May 1409 the German members of academia (called Bavarian and Saxon "nations" within the academia) separated and founded the University of Leipzig. Altogether 46 professors moved with about 5000 students and this loss of human capital brought the first deep crisis of Charles University which fell down from a major Central European education institution to e mere regional university. The crisis followed with further closure of Theological Faculty in 1419 replaced by general shift toward Protestant policies. This was period of involvement to Hussite wars and the university further declined into a Protestant Academy without licence to issue academic degrees. This continued until 1562, when king Ferdinand I called back the Jesuits which put much didactical efforts to regain academic status, renaming the Protestant Academy into Clementinum (again bearing the name of its founder), though Carolinum remained also as a name of establishments, where the university library was placed and old secular academic tradition prevailed.

With the efforts of Jesuits in 1616 previous academic status was regained giving the right to issue scholarly degrees. Following that Jesuits gained more influence over the king and got full control over Carolinum in 1622, turning it into Jesuit Academy.

However, this time the university once again involved into politics of the Thirty Years War with growing anti-Bohemian, but also antiOJesuit sentiments. In the 20s and 30s of XVII c. cardinal Ernst Adalbert von Harrach tried to return back to the clergy predominance over university affairs. He founded Collegium Adalbertinum with clear attempt to take over the chancellorship but this move was short lived as in 1638 emperor Ferdinand III took over the Church and on the basis of joined Carolinum and Clementinum put the university over imperial protection. This action took its legal decision in 1654 with creating again a single university named Charles-Ferdinand with getting back the four traditional faculties. This was not unusual in the Habsburg realm as by same period other universities in the Empire were remodeled by similar shape (like the famous Karl-Franzens University in Styrian capital Graz). 
The university also turned towards growing national sentiments when in 1784 German replaced Latin as a language of instruction and by royal decree of Leopold II in 1791 for the first time Czech was introduced to the scheme of studies. Following that in the XIX $c$ the university has further bilingual evolution with most remarkable events of the revolution of 1848 when students were advocating such linguistic democratization. It was result of drastic demographic changes of Prague when by 1860 for the first time the Germans ceased to be predominant national element in the city. But this was not yet reflected in the university teaching as only 22 university courses were in Czech and the remainder of 187 continued to be in German. During the 60s of XIX for the first time arose ideas to make two separate universities with German and Czech but the temporary bilingual status was more popular among the professors who feared the negative effects of the separation.

But the both communities were constantly dissatisfied, neither of them ready for the compromise and in 1882 by the decree of the Cisleithanian Imperial Council, sanctioned by the Emperor Franz Joseph, it was divided into what became Deutsche Karl-Ferdinands-Universitat and Ceska universita Karlo-Ferdinandova. Each part of them was entirely independent, and had equal status. The two universities shared the old insignia, the Aula, library, and botanical garden, also the medical and scientific faculties were not separated, but all common facilities were administrated by the German University.

That is why since 1882 all history of Charles University was completely divided and this resembled over each individual academic career. But following old scholarly traditions, the German University reached its academic peak in the last years preceding the First World War. Big deal of world famous scientists and intellectuals appeared among its ranks such like physicist and philosopher Ernst Mach and Albert Einstein, or as German students future writers Max Brod and Franz Kafka. Leading role in this intellectual continuity played the "Lese- und Redehalle der deutschen Studenten in Prag" ("Reading and Lecture Hall of the German students in Prague"), as an important literary and scientific centre.

When the Austro-Hungarian Empire desintegrated, the so-called Lex Mares (No. 135/1920) was issued, which ruled that the Czech university became the only legal successor to the original university. It dropped the Habsburg name Ferdinand, and retained itself as Charles University. The 
German university was not even mentioned in the document, and thus it became officially named the German University in Prague (Deutsche Universität Prag).

In 1921 the Germans decided to remove their university to Liberec (former imperial Reichenberg), in northern Bohemia. By 1930 only about 50,000 inhabitants of Prague remained with German as their native language, while millions lived in northern Bohemia near the border with Germany (or Sudetenland). These were the years of growing Czech nationalism, despite the democratic rules of the new republic and this paved the way to the future political complications with the remaining German minority (such as widely commented agrarian reform and the aggressive stance of the "Sudeten Nazis" in late 30s). Meanwhile starting the decade of 30 s ethnic tensions in the country intensified, although some professors of the German University were members of the Czechoslovak government. Escalated moods came in November 1934, when several thousand students of the Czech University gathered in front of the German university building. The reason was growing controversy over the possession of the old university insignia, at that time in the hands of the German university. These troubles of 1934 embittered for a long time ahead relations between the two universities and nationalities.

The rules drastically changed in 1938 in the course of Sudetenland crisis. Following the infamous Munich agreement, in October 1938 German troops entered the border areas of Czechoslovakia. Then Polish and Hungarian troops continued aggression annexing adjacent border territories. When on 15 March 1939 Germans forced Slovakia to split apart and the Czech lands were occupied by Nazis as the Protectorate of Bohemia and Moravia. Reichsprotektor Konstantin von Neurath returned the historical insignia to the German University, which was officially renamed as Deutsche Karls-Universität in Prag. When on 1 September 1939 the German University was placed in subordination to the Reichsministry of Education in Berlin and consequently on 4 November 1939 it was proclaimed as Reichsuniversität.

However, Czech students maintained patriotic feelings and in October 1939 organized demonstrations to protest against the subjugation of their homeland. Several students were shot and since 17 November the Czech University and all other Czech institutions of higher learning were closed, remaining closed until the end of the War (now marked as Inter- 
national Students' Day). Following these demonstrations 9 student leaders were executed and around 1,300 Czech students were imprisoned in concentration camps. And these successes were mostly seen as revenge by the German University and possibility to impose again the old German traditions. Thus, the World War II marked the end of the coexistence of the two universities in Prague with the permanent closure of its Czech counterparts and total predominance of the Germans.

Liberation from German occupation again turned down and opposite all university politics, as the Germans were losers and immediately were suffering cleansing. But despite the short period of initial misunderstandings when wide coalitions were ruling, nationalist propaganda prevailed over Germans, recalling tragic persecutions which escalated and aimed total purge of the tragic past. And the price was the complete eradication of the German element in the studies.

After 1945 the university the reestablishment of old democratic traditions facilitated the fast recovery, it did not enjoy academic freedom for longer period. With the communist coup in 1948, the new regime started persecutions and repressed all forms of disagreement with the official ideology, and continued to do so for the next decades, with the second wave of purges during the "Prague spring" period in the late $60 \mathrm{~s}$.

\section{Sources:}

1).Digitisation project 'Students of Prague Universities 1882-1945'

http://is.cuni.cz/webapps/archiv/public/?lang=en

Registries of the Charles University

Registries of the German University in Prague

Faculty of Law of the Charles University

Faculty of Law of the German University in Prague

Faculty of Science of the Charles University

Faculty of Science of the German University in Prague

Commission for Teaching (German University in Prague)

Books of examination protocols

2).Institute of the History and Archive of Charles University

Digitised Collections

https://udauk.cuni.cz/ARCHEN-29.html

KONRÁD, Ota. Dějepisectví, germanistika a slavistika na Německé univerzitě v Praze 1918-1945. Vyd. 1. Praha: Karolinum, 2011, 360 s. 
HERBER, Otto a Jan HAVRÁNEK. Insignie, medaile, taláry Univerzity Karlovy. 1. vyd. Praha: Univerzita Karlova, 1987.

ERŠIL, Jaroslav a Jiří PRAŽÁK. Archiv pražské metropolitní kapituly. 1. vyd. Praha: Univerzita Karlova, 1986. $418 \mathrm{s.}$

VANĚČEK, Václav. Karolus Quartus: Sborník vědeckých prací o době, osobnosti a díle českého krále a římského císaře Karla IV. 1. vyd. Praha: Univ. Karlova, 1984.

TŘíšKA, Josef. Studie a soupisy k starší pražské univerzitě. 1. vyd. Praha: Univerzita Karlova, 1980. Knižnice Archivu Univ. Karlovy.

HUDEC, Gustav. Studentstvo v boji proti válce, fašismu za mír: bibliografie k dějinám čsl. vysokých škol a pokrokového studentského hnutí z let 1934-1937. Praha: Universita Karlova, 1970. Sbírka pramenů a př́ruček k dějinám University Karlovy.

\section{Валентин Петрусенко}

П^овдиВския униВерситет

\section{КАРЛОВИЯТ УНИВЕРСИТЕТ В ПРАГА: МЕЖДУ НЕМСКАТА И ЧЕШКАТА АКАДЕМЧНА ТРАДИЦИЯ}

Карловият университет е най-старият в Централна Европа и е бил създаден по инициатива на Карл IV от Люксембургската династия, самият той владетел известен с ролята като покровител на културата и науката.

Докато Карловият университет е неотделима част от културния живот в Прага и Бохемиа, е бил въвлечен и в политическите противпречия на епохата, като Реформацията по чешките земи през XV в., и 30 -Годишната война през XVII в. Днес не си даваме сметка, че университетът е бил доминиран основно от немския език и германскатая академична традиция, но значителни промени настъпват след 1918 г., когато се въастановява чешката държава. Това провокира дори разрив между немската и чешка научни общности и последвалото отделяне не немскоезичен университет извън Прага. Докладът ще се фокусира върху тези драматични години за откриването на новата концепция за национален чешки университет, неговият кратък възход до известните европейски университети през междувоенния период, последвал от мрачните години на немската окупация.

Ключови думи: Карловият университет, Карл IV Люксембург, немска и чешка академични традиции. 